\title{
Література:
}

1. Косенко Г.Г. Темброва семантика альта у творчості харківських композиторів 1960 - 2000 -х років: дис. ...канд. мистецтвознавства: 17.00.03 / Харків, Харківський нац. ун - т. мистецтв ім. Котляревського, 2018. $222 \mathrm{c}$.

2. Купріяненко Е.Б. Альт у політембровому камерно інструментальному ансамблі австро - німецької традиції (пізнє барокко Й. Брамс): автореф. дис. ... канд. мистецтвознавства. Харків, 2010. 21 с.

3. Маклыгин А. Фактурные формы сонорной музыки /сост. Ценова В.С., Сторожко Л.М. М., 1992. С. 129 -137.

DOI https://doi.org/10.30525/978-9934-26-004-9-132

\section{INITIAL POSITIONS FOR THE FORMATION OF THE PROFESSIONAL MEMORY OF A MUSICIAN-PERFORMER}

\author{
Sapsovych O. A. \\ Candidate in Art Studies, \\ Doctoral Student at the History of Music \\ and Musical Ethnography Department, \\ Associate Professor at the Special Piano Department \\ Odessa National A. V. Nezhdanova Academy of Music \\ Odesa, Ukraine
}

The professional memory of a musician-performer is one of the key phenomena that permeate all the musician's activities, starting from the very first steps in the professional field. The level of success of ones musical activity largely depends on the correctness of the algorithm of «including» various aspects of professional memory into the musician's training. It is not only about the ability to memorize, reproduce from memory and «hold in fingers» for as long as possible a musical text. Professional memory directly affects the ability to build an original interpretation, the richness of sound production, the timbre-dynamic performance capabilities, the level of virtuosity, the ability to listen and hear oneself, analyze and work constructively on one's own skill. This is a multi-component phenomenon, the various aspects of which are subdivided into interdependent facets: there is a physical level of perception, mastering and further preservation of the text, covering the auditory, visual and kinesthetic aspects, where the visual 
encompasses musical notation and keyboard topography, kinesthetic, in turn, breaks down into tactile and motor components. There is a level that is responsible for rationality and is embodied at the constructive-logical level of «squeezing» with musical texture, and finally, the most important level of memory serves to build a figurative-semantic scenario and includes the emotional memory of the musician.

As for the training at the «zero» level, from which begins, with varying degrees of correctness and ergonomics, the development of a musician's professional memory, in the teaching methodology there are three main directions of the initial stages of children's musical education.

The first direction is based on the mastery of the information necessary to read the musical notation. Here, at the forefront is the process of acquiring pianotechnical skills and their automation. Until the student masters all this, the road leading to music is partially, and sometimes completely blocked. L. A. Barenboim was very critical about this tendency in his book «The Way to Making Music», summarizing: «to lay a solid foundation for technique and literacy $\langle\ldots\rangle$ everything else will follow and can be left to chance for now» [2].

The second direction chooses auditory education, the formation of musical ear as the main vector. Adherents of this tendency, acknowledging the importance of literacy and the development of the pianist's technical equipment, put these parameters, nevertheless, in the second place, and not only in essence, but also literally in terms of mastering time: first, there is a training in musical and auditory analysis, and only then - an appeal to the constructive-logical and technical aspects of the musical piece.

The third direction, the dominant core of the piano-pedagogical work, is the education of the child's personality, through the development of his creative abilities and for the creative mastery of music language.

The first, as you can see, begins with putting constructive-logical elements of reading and perception of a musical text into the musician's «memory box» for its further reproduction. Certain elements of tactile and motor memory (hand positioning) are immediately grafted and activated. Despite the fact that many outstanding teachers actively criticized this approach, with all the declarative nature of the fact that this is not the path of truth, practice shows that this method was used and is still used by the teachers of the piano class in their absolute majority. One of the most vivid reflective essays about how unnatural for a beginner such a path «into music» is, probably today remains the autobiographical, retrospective psychoanalysis undertaken by M. Tsvetaeva in her work «Mother and Music». Here is a small excerpt from it: «The note-keyboard process is as much more complicated than the alphanumeric-vocal process, how much more complicated the keys themselves 
are - from my own voice. $<\ldots>$ If between me and the keyboard there were notes, then between the note and me - the keyboard came up, constantly lost because of the sheet of music. Not to mention the simple, obvious sense of the word being read and the quite divine sense of the measure played. Reading, I translate into meaning, while playing, I translate into sound, which, in turn, must be translated into something, otherwise the sound is empty. But when should I, five years old, feel and express this feeling, when I am already looking again: first with my eyes, on a ruler, a sign, then, in my mind, corresponding to this sign - the notes of the scale, then - with my finger - the keys corresponding to this note? There is a game with three unknowns, but for a five-year-old it is enough - one, followed by another, always, another, which is only an input into a larger unknown, which is behind all meaning and sound, into a huge unknown - the soul»[5].

The outstanding representatives of the second and third directions include such performers-teachers and methodologists as: K. A. Martinsen, who analyzes, among other things, in his book «Individual Piano Technique» the complex of the prodigy - Mozart. The author emphasizes that: «In <...> early musical development, the primary driver is not mental learning, but sensation, auditory and sound sensation» [3, p. 21]. The essence of what was stated by the researcher, which found a response among many teachers of the piano class, can be formulated as follows: pedagogical adaptation to the need of independent vigorous activity dictated by the child's auditory will, determines the form of learning «playfully» in the child's own understanding of the word - «playing» music without reference to routine component of the pianistic craft. Execution motorics should not be the primary goal of the initial stage. This approach is rooted in the pedagogy of L. Mozart. «Wolfgang could play things for which he did not even have the slightest mastery of what is usually called technique. He played what his ear wanted, without thinking at all about the fingers, "although completely with incorrect and inappropriate fingering" «[Cit. according to: 3, p. 23]. The same approach was further practiced on his talented daughters by F. Wieck, giving the «pre-piano» period of music education about 1 year.

A. D. Artobolevskaya also speaks about the extraordinary significance and benefits of such a «pre-piano» period in her book «The First Meeting with Music». In her pedagogical doctrine, she paid special attention to the creative development of the student, enriching his work with tasks that, to a certain extent, develop an improvisational gift: versification, going in parallel with the learning of characteristic pieces, transposition, starting with the first pieces learned. These methods can be attributed to the third direction indicated above. However, the second direction, suggesting the primacy of the child's filling 
with music outside of theory, was a key point for her. It is evident that the second and third directions are characterized by the «inclusion» and folding of auditory images into the personal musical archive of a young musician without reference to their correct, in terms of motor parameters, independent reproduction. G.G. Neuhaus succinctly speaks of the importance of the latter in his book about piano mastery: «Before starting to learn on any instrument, a learner - be it a child, adolescent or adult - must already spiritually own some kind of music; so to speak, keep it in your mind, carry it in your soul and hear with your ear. The whole secret of talent and genius lies in the fact that music already lives in full life in his brain before he first touches the key or moves his bow along the string; that is why, as a baby, Mozart «immediately» began to play the piano and the violin» [4, p. 11].

From the above, it follows that the most important stage in the formation of the basics of the professional memory of a musician-performer should begin with the process of frequent listening to music. Thus, that musical «soil» is created in which «the teacher seeks to sow his seeds» [1, p. 10]. After such a perception, which is, in essence, the synthesis of not only auditory, but also emotional memory (the most important and so little studied aspect), the process of reproducing music that was already deposited in the student's memory is carried out by means of selection by ear (the complex of the prodigy Mozart - as a reflection of methods of his father Leopold [3]). This gives rise to the intentionality of sound presentation - the first link in communication with music already through the instrument - the first layer of professional memory in practice.

At the same time, there is an accumulation in the memory of some techniques of motor skills that form not a cult of technology, but the foundations of free pianism (which was described in great detail by A. Artobolevskaya [1]). And only after that, is the inclusion and interweaving of the conscious visual and constructive-logical aspects into the aspects of auditory, emotional and motor memory. That at the output creates an ideal, from the point of view of the psychophysical direction of pedagogy, a construction where hearing is not a passive analyzer of the already taken sound, but its «directorial» fundamental principle.

\section{References:}

1. Артоболевская А. Д. Первая встреча с музыкой. Москва : Советский композитор, 1985. 101 c. URL: https://notkinastya.ru/ artobolevskaya-a-pdf/ (date of access 04.11.2020)

2. Баренбойм Л. А. Пусть к музицированию. Ленинград : Сов. композитор, 1976. $269 \mathrm{c}$. 
3. Мартинсен К. А. Индивидуальная фортепианная техника. Москва : Музыка, 1996. 220 с.

4. Нейгауз Г. Г. Об искусстве фортепианной игры. Записки педагога. Москва : Музыка, 1958. 207 с.

5. Цветаева М. Мать и музыка. URL: http://tsvetaeva.litinfo.ru/tsvetaeva/proza/mat-i-muzyka.htm (date of access 05.11.2020)

DOI https://doi.org/10.30525/978-9934-26-004-9-133

\title{
ІСТОРІЯ СЦЕНІЧНОГО ВТІЛЕННЯ МУЗИЧНО-ТЕАТРАЛЬНИХ ПОСТАНОВОК ЗА МУЗИЧНОЮ П'ССОЮ «ІВАСИК-ТЕЛЕСИК» М. КРОПИВНИЦЬКОГО
}

\author{
Стьопіна А. Ю. \\ аспірантка кафедри інтерпретології та аналізу музики \\ Харківського національного університету мистецтв \\ імені І. П. Котляревського \\ м. Харків, Україна
}

Дитяча музична п’єса «Івасик-Телесик» за мотивами української народної казки видатного українського драматурга, композитора, режисера, одного із засновників Театру українських корифеїв, разом 3 оперою класика української музики Кирила Стеценка - створили не лише фундамент репертуару молодого українського театру для дітей, а й дали основу для подальшого розвитку всієї дитячої драматургії в Україні. В статті зроблено короткий огляд музично-драматичних версій «ІвасикаТелесика» Марка Кропивницького на прикладі музично-драматичних дійств А. Коломійця «Івасик-Телесик», І. Щербакова «Пастка для Відьми», О. Джона Сука «Золотий човник». Відсутність наукових розвідок, які б повно і всебічно висвітлювали сценічні втілення музичної дитячої п’єси М. Кропивницького «Івасик-Телесик» та їх значення для розвитку музичного дитячого театру на Україні, вказує на необхідність більш грунтовного дослідження та актуальність обраної теми.

Ведучи літопис українського дитячого театру ще з його виникнення в дожовтневі часи, ми не можемо обійти ані дитячих п'єс Марка Кропивницького, ані їх сценічного втілення дітьми ще у передреволюційні роки. Однією зі значних, але маловідомих сторін творчої діяльності драматурга було створення дитячої трупи, яка на його думку, могла б стати основою українського дитячого театру. 